\title{
A Study on Factors Influencing Job Perception and Job Performance of PDOs: An Empirical Evidence in Case of Karnataka, India
}

\author{
M.V. Bharamagoudar* and J.G. Angadi \\ Department of Agricultural Extension Education, U.A.S, Dharwad, India \\ *Corresponding author
}

\begin{tabular}{|l|}
\hline Key w o r d s \\
Perception, \\
Performance, \\
Regression, \\
Karnataka, \\
Promotion and \\
Opportunities \\
\hline Article Info \\
\hline $\begin{array}{l}\text { Accepted: } \\
\text { 30 December } 2018 \\
\text { Available Online: } \\
\text { 10 January } 2019\end{array}$ \\
\hline
\end{tabular}

\section{A B S T R A C T}

The present study was undertaken to analyze the Job perception and job performance of Panchaya Development officers in Karnataka State during the year 2013-2014. The study area includes Dharwad, Haveri, Bagalkot and Bijapur districts of northern Karnataka. The Ex-post facto' research design was employed for the study. Further, the PDOs working in Dharwad, Haveri. Bagalkot and Bijapur districts were selected as the population for the study. From each districts 38 PDOs were selected by simple random sampling to form total sample of 152 respondents'. The results revealed that coefficients of determination $\left(\mathrm{R}^{2}\right)$ were 0.671 and 0.583 for job perception and job performance, respectively. The results further imply that all the selected eight independent variables put together contributed 67.10 per cent and 58.30 per cent of variation in job perception and job performance of PDOs respectively. In addition, study also reveals that, the constraints in job performance of PDOs shows that, all most 96 per cent of PDOs perceived that they come across with interference of local representatives in performing job activities this coupled with Over workload was the second major constraint as perceived by 83.55 per cent of PDOs. Further, Majority of PDOs perceived co-workers are not co-operating (69.74\%), lack of recognition or appreciation for good work (61.84\%), lack of time to implement the programmes $(56.58 \%)$ and lack of promotion opportunities $(56.58 \%)$ as other constraints in effective job performance.

\section{Introduction}

The Gram Panchayat (GP) in the State implements a large number of Central/State sector schemes/programmes and substantial funds are released to the GPs. The staff members working in the GPs were not qualified and were not permanent. Many works/schemes executed by the GPs were technical in nature and none of the GPs were equipped with technical staff. However, with respect to Job Perception and Performance programmes are among the most helpful tools at any government or private organizations, which can be used to maintain and enhance productivity and facilitate progress toward strategic goals. While we will focus mainly on job perception and job performance, the processes of monitor the way employees work and assess how this matches organizational needs. They form impressions about the relative value of employees to the organization 
and seek to maximize the contribution of every individual. This study aims to explain the factors responsible of job perception and performance. The success or failure of job perception and performance program depends on the philosophy underlying it, its connection with organization goals, and the attitudes and skills of those responsible for its overall development. Many different methods can be used to gather information about employee job perception and performance. The information can be evaluated in the context of organizational needs and communicated to employees so that it will result in high levels of performance. There should be many benefits to implementing a regular and systematic performance system within an organization and perception towards job can be increased. In order to gain the most benefit from job performance it is recommended that a system is developed in consultation with workers and managers, and clear links are established between appraisals and valued rewards and outcomes. If resources permit, information on work performance should be obtained from multiple sources. Performance and perception can be a powerful tool for increasing motivation and improving work practice if conducted in a constructive, open and supportive manner. Apart from these functions, Gram pachayat also plays vital role in field publicity of matters connected with development works and other welfare measures undertaken by the State Government. PDO has many roles and responsibilities in overall development. The main function is to act as a channel through which Government assistance should reach the residents of the Gram Panchayat or any rural community.

Thus the panchayat development officer plays the role of a 'catalyst' and addresses issues of service delivery and proper implementation of rural development schemes. Five years have completed since creation of the post of PDO. There is need to ascertain the job perception and job performance of PDOs. Moreover, there is no tool to measure the job perception and job performance of PDOs. Keeping this in view, the present study was undertaken to study the factors influencing job perception and job performance of Panchayat Development Officers.

\section{Materials and Methods}

The present study was undertaken to analyze the job performance of Panchaya Development officers in Karnataka State during the year 2013-2014. The study area includes Dharwad, Haveri, Bagalkot and Bijapur districts of northern Karnataka. The Ex-post facto' research design was employed for the study. Further, the PDOs working in Dharwad, Haveri. Bagalkot and Bijapur districts were selected as the population for the study. From each districts 38 PDOs were selected by simple random sampling to form total sample of 152 respondents'. The samples were further subjected to multiple regressions to fulfill derised objective of the study. The details as mentioned below:

\section{Multiple regression analysis}

Stepwise Multiple Regression Analysis was done to locate the variables that had strongest impact on the dependent variable. $\mathrm{R}^{2}$ value was determined and $\mathrm{F}$ test was also employed. In step one of the stepwise multiple regression, the independent variable, which was highly correlated with the dependent variable was included in the equation. At the same time, the coefficient of determination $\left(\mathrm{R}^{2}\right)$ was also computed. In the second step, among the remaining independent variables the variable, which had second highest correlation with the dependent variable was entered to the equation. This process was repeated for all the independent variables. Multiple regression function was as following to find out their contribution to the variation in dependent variable. 
$\mathrm{Y}=\mathrm{f}(\mathrm{A}, \mathrm{E}, \mathrm{PW}, \mathrm{ISB}, \mathrm{JI}, \mathrm{JS}, \mathrm{JSF}, \mathrm{F})$

Where $\mathrm{A}=\mathrm{Age}$

$\mathrm{E}=$ Education,

ISB=Information seeking behaviour

$\mathrm{PW}=$ Perceived workload

$\mathrm{JI}=\mathrm{J}$ ob involvement

$\mathrm{JS}=\mathrm{Job}$ stress

$\mathrm{JSF}=\mathrm{Job}$ satisfaction

$\mathrm{F}=$ Facilities and resources

Coefficient of determination $\left(\mathrm{R}^{2}\right)$ revealed percentage of variation in the dependent variable explained jointly by the independent variables. $\mathrm{R}^{2}$ value reflects the extent of errors made when using the regression model to guess the value of the coefficients of the dependent variable.

$\mathrm{R}^{2}$ value $=(1-(\mathrm{ESS} / \mathrm{TSS})$

Where ESS = Error sum of squares

TSS $=$ Total sum of squares

F - test

The $\mathrm{F}$ test was used to test the significance of $\mathrm{R}^{2}$ value. $\mathrm{F}$ value was computed using following equation and compared with the Table value at ( $n-k-1)$ degrees of freedom.

$\mathrm{F}$ value $=\frac{\left(\mathrm{R}^{2} / \mathrm{k}\right)}{\left(1-\mathrm{R}^{2}\right) /(\mathrm{n}-\mathrm{k}-1)}$

$\mathrm{R}^{2}=$ Coefficient of multiple determination

$\mathrm{n}=$ Number of pairs of observations

$\mathrm{k}=$ Number of variables

\section{Results and Discussion}

Stepwise multiple regression analysis was carried out to identify those variables which contribute significantly towards variation in job perception and job performance of PDOs. The results of multiple regression analysis are presented in Tables 1 and 2. The paper presents its result in 2 subheads such as factor and constraints in job perception and job performance.

\section{Factors influencing job perception and job performance of PDOs}

A careful observation of the results revealed that coefficients of determination $\left(\mathrm{R}^{2}\right)$ were 0.671 and 0.583 for job perception and job performance, respectively. The results further imply that all the selected eight independent variables put together contributed 67.10 per cent and 58.30 per cent of variation in job perception and job performance of PDOs respectively.

The computed regression coefficients showed that, among eight independent variables only two variables namely age and job satisfaction contributed significantly towards influencing the level of job perception of PDOs. In case of job performance three variables namely age, information seeking behavior and facilities and resources significantly contributed for variation in job performance of PDOs.

It is clear from the results of stepwise multiple regression analysis presented in Table 1 and Table 2 that all the independent variables considered in the study together exerted significant influence on the job perception and job performance of the respondents. It implied that the variation in the job perception and job performance of PDOs was due to the combined influence of all the 8 variables studied for this purpose. An analysis of coefficient of determination revealed that independent variables contributed to the extent of 67.1 and 58.3 per cent variation in job perception and job performance of PDOs, respectively.

The results presented in the table, also pointed out that four independent variables namely 
age, job satisfaction, job stress and facilities and resources contributed significantly towards the variation in the job perception of the PDOs. Whereas, five independent variables namely age, education, information seeking behavior, job satisfaction and facilities and resources contributed significantly towards the variation in the job performance of PDOs. Further, in the light of significant contributions made by the above-mentioned variables towards job perception and job performance of the respondents.

These variables can be considered as good predictors of job perception and job performance of PDOs. These results reinforce the findings of association of job perception and job performance with personal and job related characteristics of PDOs.

Table.1 Multiple regression analysis of the independent variables with job perception of PDOs

\begin{tabular}{|c|c|c|c|c|}
\hline $\begin{array}{l}\text { Sl. } \\
\text { No. }\end{array}$ & Independent variables & $\begin{array}{c}\text { Regression } \\
\text { coefficients (b) }\end{array}$ & 't' value & P-value \\
\hline 1 & Age & 0.412 & $3.392 *$ & 0.000898 \\
\hline 2 & Education & 0.666 & $0.390^{\mathrm{NS}}$ & 0.696932 \\
\hline 3 & Information seeking behavior & 0.163 & $0.783^{\mathrm{NS}}$ & 0.434922 \\
\hline 4 & Perceived work load & -0.730 & $-1.204^{\mathrm{NS}}$ & 0.230712 \\
\hline 5 & Job satisfaction & 0.217 & $2.638 *$ & 0.009272 \\
\hline 6 & Job involvement & -0.081 & $-1.012^{\mathrm{NS}}$ & 0.313341 \\
\hline 7 & Job stress & -0.022 & $-0.255^{\mathrm{NS}}$ & 0.798792 \\
\hline 8 & Facilities and resources & 0.300 & $1.785^{\mathrm{NS}}$ & 0.076335 \\
\hline \multirow{3}{*}{\multicolumn{2}{|c|}{$\begin{array}{ll}\text { Coefficient of determination }\left(\mathrm{R}^{2}\right) & = \\
\mathrm{F} & = \\
\text { Intercept } & =\end{array}$}} & 0.671 & \multirow{3}{*}{\multicolumn{2}{|c|}{$\begin{array}{l}* \text { - Significant at } 0.05 \% \\
\text { NS - Non-significant }\end{array}$}} \\
\hline & & 4.88 & & \\
\hline & & 52.37 & & \\
\hline
\end{tabular}

Table.2 Multiple regression analysis of the independent variables with job performance of PDOs

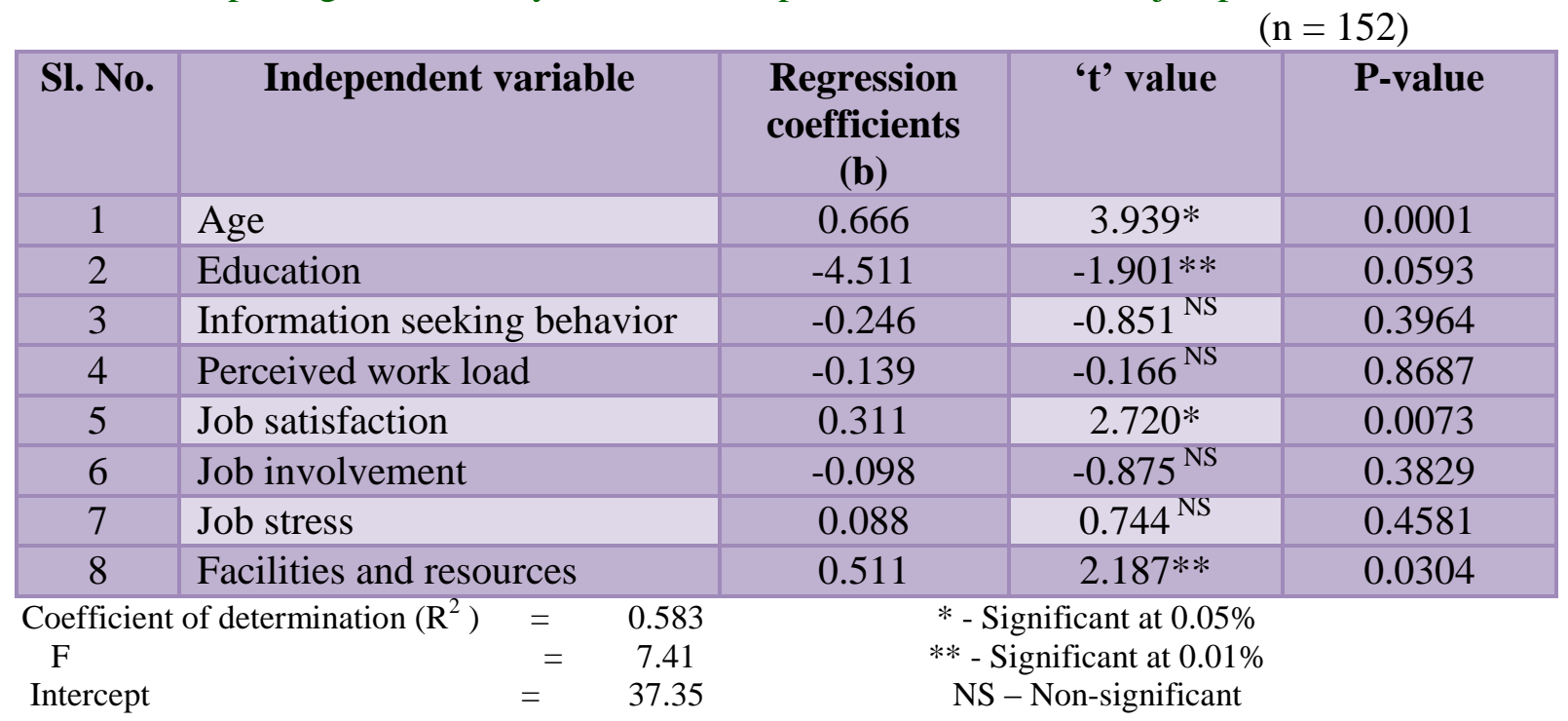


Table.3 Constraints in job performance of PDOs

\begin{tabular}{|c|l|c|c|}
\hline $\begin{array}{c}\text { Sl. } \\
\text { No. }\end{array}$ & \multicolumn{1}{|c|}{ Constraints } & Frequency & Percentage \\
\hline 1 & $\begin{array}{l}\text { Political interference in implementation of } \\
\text { schemes/programmes }\end{array}$ & 146 & 96.05 \\
\hline 2 & $\begin{array}{l}\text { Over workload } \\
\text { Coworkers are not co-operating }\end{array}$ & 127 & 83.55 \\
\hline 3 & Lack of recognition/appreciation for good work & 94 & 69.74 \\
\hline 4 & Lack of time to implement the programmes & 86 & 56.84 \\
\hline 5 & Lack & 86 & 56.58 \\
\hline 6 & Lack of promotional opportunities & 74 & 48.68 \\
\hline 7 & $\begin{array}{l}\text { Information relevant to work is not properly } \\
\text { communicated }\end{array}$ & 72 & 47.37 \\
\hline 8 & $\begin{array}{l}\text { Superiors will not guide and help in problematic } \\
\text { situation }\end{array}$ & 47 & 30.92 \\
\hline 9 & Frequent transfers & & \\
\hline
\end{tabular}

\section{Constraints in job performance of PDOs}

Constraints in job performance of PDOs are given in Table 3. All most all PDOs (96.05\%) perceived that they come across with interference of local representatives in performing job activities. Over workload was the second major constraint as perceived by 83.55 per cent of PDOs. Majority of PDOs perceived co-workers are not co-operating (69.74\%), lack of recognition or appreciation for good work $(61.84 \%)$, lack of time to implement the programmes $(56.58 \%)$ and lack of promotion opportunities $(56.58 \%)$ as other constraints in effective job performance.

A perusal of the Table 3 indicated the problems encountered by PDOs in performing their job. Political interference in implementing programmes or schemes was the major constraint experienced by PDOs. Panchayat being a demostratic organization, all the programmes and schemes are planned and implemented by panchayat itself and non official members have a great say in implementing programmes. PDOs felt stress of interference and expressed lack of freedom in implementation of programme. Over workload was the second major constraints perceived by PDOs, exist a number of vacant posts in the organization and involvement of PDOs is there in implementation of many programmes of the government. Along with implementation of programmes, PDOs are also involved in reporting of progress to the higher authorities. These might have led to perceiving workload as heavy by majority of PDOs.

The other problem perceived by PDOs was co-workers are not co-operating. Majority of co-workers were localities and for the good or the bad they exert influence. They are in touch with the local representatives. This has led to the perception of PDOs that co-workers are not cooperative and act independently.

Further, Lack of time to implement all the programme was the other constraint expressed by PDOs. As discussed earlier, PDOs felt over load with work involvement in several other programmes naturally, they felt lack of time for implementation of all the programmes.

Lack of promotional opportunity was the constraint expressed by a simple majority of PDOs (56.58\%). PDOs expressed that there 
should be provision for promotion based on experience and performance. They feel that this will motivate them to perform consistently.

\section{Constraints in job performance of PDOs}

All most all (96.05\%) PDOs expressed "Political interference in implementation schemes/programmes" as most vital problem followed by 'over workload' (83.55\%).

Lack of co-operation by co-workers, recognition or appreciation for good work, lack of promotion scheme and lack of time to implement the programme were constraints in job performance by PDOs.

\section{References}

David, K. M. and Robert, A. M., 2013, Perceptions regarding selected educational strategies used by extension educators. J. Agric. Edu. Extn., 19(4): 395-406.

Halakatti, S. V. and Sundaraswamy, B., 1997, Organizational climate, perception of Agricultural Assistants in Karnataka. $J$. Extn. Edu., 8(3): 1763-1765.

Jadhav, S. G., Ahire, M. C. and Patil, S. D. 2011, Role perception of women members in dairy co-operative societies. Mysore J. Agric. Sci., 45(4): 883-886.

Josiah, O. A. and Adeyinka, T., 2007, University undergraduate students' information seeking behaviour: implications for quality in higher education in Africa. The Turkish J. Edu. Technol., 6(1): 1303-6521.

Karad, B. D., 2010, Job stress in information technology sector - the cause and effect analysis. J. Comm. Mngt. Thought, 1(3): 247-271.

Kiran, T. R., 2007, Perception of organisational climate by scientists of University of Agricultural Sciences,
Dharwad. M. Sc. (Agri.) Thesis, Univ. Agric. Sci., Dharwad, Karnataka (India).

Kolte, N. V., 1972, Prediction of effective job performance of Agricultural Extension Officers of the community development blocks. Ph. D. Thesis, Univ. Udaipur, Udaipur.

Manjula, N., 2000, A study on job perception, job performance and job satisfaction of AAOs in Karnataka. Ph. D. Thesis, Univ. Agric. Sci., Bengaluru, Karnataka (India).

Manjunath, L. and Shashidahra, K. K., 2011, Determinates of scientific productivity of agricultural scientists. Indian Res. J. Extn. Edu., 11(1): 7-12.

Meti, U., 1992, A study of perception of organisational climate and job satisfaction of Agricultural Assistants in NAEP. M. Sc. (Agri.) Thesis, Univ. Agric. Sci., Bengaluru, Karnataka (India).

Mitchell, B., 1973, An analysis of the perception of the role of subordinate and superordinate with respect to authority, responsibility and delegation in the community schools of flint at the attendance centre level. Ph. D. Thesis, Univ. Agric. Sci., Bengaluru, Karnataka (India).

Mohammad, J. H. and Koichi, U., 2007, Effects of agricultural extension workers' perceptions of off-the-job training and on the job training to the development of their skills. American J. Agric. Biol. Sci., 2(3): 184-190.

Mohan, B., 2000, A study on job performance and job satisfaction of Assistant Agricultural Officers in Northern districts of Karnataka. M. Sc. (Agri.) Thesis, Univ. Agric. Sci., Dharwad, Karnataka (India).

Mudau, F. N. and Kruger, J. W., 2014, Students perception on the entrepreneurship curriculum at the 
University of South Africa's department of agriculture and animal health. $J$. Human Ecol., 46(1): 91-101.

Muhammad, R. I., Mostafizur, M. U., Rahman, A., Pervez, K. M., Muhammad, A. P. and Kamaly, H. K., 2013, Perception of extension agents about sustainable agricultural practices in Bangladesh. Int. J. Agric. Extn., 1(12): 15-19.

Nagananda, C., 2005, Study of organizational climate perception of Assistant Directors of Agriculture and Agricultural Officers of KSDA. M. Sc. (Agri.) Thesis, Univ. Agric. Sci., Dharwad, Karnataka (India).

Pavitra, C. H. and Manjunath, L., 2014, Perception and usefulness of Yashaswini health scheme in Karnataka. Karnataka J. Agric. Sci., 27(2): 184-189.

Sandika, A. L., 2006, A study on organizational climate Perception by Veterinary Officers (VOs) and Veterinary Livestock Inspectors (VLIs) of Department of Animal Husbandry and Veterinary Service, Karnataka. $M$. Sc. (Agri.) Thesis, Univ. Agric. Sci.,
Dharwad, Karnataka (India).

Satish Kumar, G. D. and Popat, M. N., 2009, Development of a scale to measure farmers' perceptions on quality of groundnut. Indian Res. J. Extn. Edu., 9(1): 11-13.

Shamna, A, K., Narayanagowda, Shivalingegowda N. S and Suresha, S. V., 2012, A scale to measure performance of village resource centres on farming activities in Karnataka. Indian Res. J. Extn. Edu., 12 (1): 39-43.

Shivalingegowda, N. S., 1985, A study on job perception, job performance and job satisfaction of extension guides in Karnataka. M. Sc. (Agri.) Thesis, Univ. Agric. Sci., Bengaluru, Karnataka (India).

Singh, H. C. and Rajesh Kumar, 2012, Role perception of the trainers of Krishi Vigyan Kendras. Indian Res. J. Extn. Edu., 12(1): 83-86.

Singh, M. P., 1970, Measurement and prediction of job performance of Block Development Officers in IAAP and IADP block of Bihar. Ph. D. Thesis, Indian Agricultural Research Institute (IARI), New Delhi (India).

\section{How to cite this article:}

Bharamagoudar, M.V. and Angadi, J.G. 2019. A Study on Factors Influencing Job Perception and Job Performance of PDOs: An Empirical Evidence in Case of Karnataka, India. Int.J.Curr.Microbiol.App.Sci. 8(01): 3162-3168. doi: https://doi.org/10.20546/ijcmas.2019.801.338 